\title{
Strategi Pengurangan Risiko Bencana Kebakaran di Kawasan Permukiman Padat Melalui Peningkatan Kapasitas Masyarakat di Kapas Madya Baru
}

\author{
Tri Okta Argarini dan Mochamad Yusuf \\ Departemen Perencanaan Wilayah dan Kota, Fakultas Teknik Sipil, Perencanaan, dan Kebumian, \\ Institut Teknologi Sepuluh Nopember (ITS) \\ e-mail: trioktaargarini38@gmail.com
}

\begin{abstract}
Abstrak-Kapas Madya Baru merupakan salah satu kelurahan di Kota Surabaya yang memiliki risiko tinggi kebakaran. Walaupun memiliki tingkat bahaya kebakaran pada level sedang, kondisi kerentanan yang tinggi harus diimbangi dengan kapasitas yang tinggi pula. Saat ini, terdapat indikasi rendahnya kapasitas masyarakat karena minimnya pengetahuan dan kemampuan dalam antisipasi kebakaran. Sedangkan, peningkatan kapasitas masyarakat pada tahap pra-bencana belum menjadi agenda prioritas Pemerintah Kota Surabaya yang dilihat dari belum adanya pengukuran kapasitas masyarakat. Penelitian ini dilakukan untuk merumuskan strategi peningkatan kapasitas masyarakat di Kelurahan Kapas Madya Baru dengan mengkaji tingkat kapasitas masyarakat dan faktor yang memengaruhi kapasitas tersebut. Metode pengambilan data dilakukan dengan survei lapangan untuk memperoleh data kondisi masyarakat kemudian dianalisis menggunakan Weighted Mean Score (WMS), Analisis Faktor, serta SWOT dalam merumuskan strategi. Dari hasil analisis, didapatkan bahwa kapasitas masyarakat berada pada level cukup baik, sementara faktor yang mempengaruhi kapasitas masyarakat adalah kualitas SDM (Sumber Daya Manusia) dan tata kelola. Strategi yang dirumuskan dalam penelitian ini dibagi menjadi 3 tahap. Pertama, strategi pada tahap mitigasi berfokus pada peningkatan kesiapan alat pemadam, penertiban bangunan yang menghambat pemadaman api, pengembangan sistem jaringan supply air, pembuatan aturan antisipasi kebakaran di lingkup RT, peningkatan sosialisasi dan simulasi melalui kerjasama elemen masyarakat, peningkatan pemahaman masyarakat melalui perlombaan, pengembangan sistem mitigasi berbasis teknologi, edukasi praktik aman penggunaan listrik, jaring aspirasi masyarakat dalam penyusunan kebijakan, dan evaluasi Perwali No. 57 Tahun 2014. Kedua, tahap kesiapsiagaan berfokus kepada pembuatan konsep evakuasi disertai edukasinya, pembuatan penanda bencana, dan membangun kemitraan. Ketiga, tahap peringatan dini berfokus pada pengembangan sistem peringatan dini dan pembagian tugas tanggap darurat.
\end{abstract}

Kata Kunci-Kapasitas Masyarakat, Kesiapsiagaan, Mitigasi, Peringatan Dini.

\section{PENDAHULUAN}

$\mathrm{K}$ AWASAN dengan lahan terbangun yang padat menjadi salah satu penyebab rawan terjadinya kebakaran. Surabaya menjadi perkotaan yang memiliki risiko tinggi kebakaran [1][2]. Risiko kebakaran adalah potensi kerugian yang ditimbulkan akibat kebakaran pada suatu wilayah dalam kurun waktu tertentu [2]. Sepanjang Januari sampai Oktober tahun 2019, jumlah kejadian kebakaran di Surabaya tercatatat sebanyak 670 kasus dengan kerugian mencapai Rp17 miliar, 23 orang luka-luka, dan 1 orang meninggal dunia [3]. Kebakaran perumahan menyumbang frekuensi tertinggi pada kategori kebakaran bangunan di bulan Juli 2019 [4].

Sebuah penelitian risiko kebakaran menggunakan Sistem Informasi Geografis menunjukkan bahwa Kelurahan Kapas Madya Baru menjadi daerah dengan risiko tinggi terjadi kebakaran. Dilihat dari kondisi fisik, sosial, ekonomi, dan lingkungan, wilayah tersebut memiliki kerentanan yang tergolong tinggi [3]. Dengan kepadatan penduduk yang tinggi, jarak antar bangunan rumah terlalu rapat disertai dengan kondisi akses yang sempit menjadi gambaran kondisi di lapangan. Selain itu, Kelurahan Kapas Madya Baru tercatat memiliki jumlah keluarga pra-sejahtera terbanyak kedua di Kecamatan Tambaksari [5]. Kondisi kemiskinan memiliki hubungan linier dengan kerentanan, bahwa masyarakat dengan kemampuan ekonomi yang rendah akan lebih rentan terpapar kebakaran [6].

Berdasarkan data historis kebakaran, Kelurahan Kapas Madya Baru memiliki tingkat bahaya kategori sedang [3]. Dari tahun 2016 hingga 2019, total kejadian kebakaran di wilayah tersebut disebabkan oleh api terbuka (41\%) dan arus pendek (53\%) [6]. Api terbuka dapat bersumber dari kompor, gas LPG, korek api, obat nyamuk, dan lainnya yang diakibatkan oleh kelalaian masyarakat dalam penggunaan sumber api untuk kebutuhan sehari-hari. Sedangkan, korsleting listrik pada banyak kasus disebabkan oleh penggunaan alat listrik yang tidak sesuai standar serta beban berlebih di titik stop kontak dan peralatan elektronik [7]. Hal tersebut mengindikasi rendahnya kapasitas masyarakat di Kelurahan Kapas Madya Baru.

Kapasitas masyarakat diartikan sebagai kemampuan masyarakat untuk mengurangi tingkat ancaman dan kerugian akibat bencana [8]. Kapasitas memiliki nilai terbalik dengan bahaya dan kerentanan dimana semakin tinggi kapasitas akan menurunkan risiko bencana. Peningkatan kapasitas masyarakat dapat dilakukan melalui tiga siklus manajemen bencana yaitu sebelum terjadi bencana/prabencana yang bersifat preventif, tahap ketika terjadi bencana/respons time yang bersifat tanggap darurat, dan tahap setelah bencana terjadi/pascabencana yang bersifat pemulihan [9]. Upaya peningkatan kapasitas masyarakat yang dilakukan pada tahap 
prabencana melalui sosialisasi dan edukasi ke masyarakat merupakan salah satu upaya kesiapsiagaan yang menentukan keberhasilan pengurangan risiko bencana [10]. Hal tersebut sejalan dengan pernyataan Bank Dunia dan Survei Geologi AS bahwa investasi prabencana sebanyak $\$ 40$ miliar, dapat mengurangi kerugian sebesar \$280 miliar akibat bencana.

Akan tetapi, upaya peningkatan kapasitas masyarakat sering kali belum dijadikan agenda prioritas pemerintah, termasuk Pemerintah Kota Surabaya, yang dapat dilihat dari belum dilakukannya pengukuran kapasitas masyarakat. Pemerintah Kota Surabaya lebih berfokus pada penyediaan infrastruktur darurat bencana seperti mobil pemadam daripada peningkatan kapasitas masyarakat sebelum bencana terjadi. Berdasarkan Masterplan Dinas PMK Kota Surabaya tahun 2017-2022, dari total anggaran sebanyak Rp964 triliun, hanya 0,5\% atau Rp5 miliar yang digunakan untuk pemberdayaan kelembagaan pemadam kebakaran di masyarakat, salah satunya sosialisasi dan edukasi kepada masyarakat.

Oleh karena itu, diperlukan penelitian mengenai strategi peningkatan kapasitas masyarakat dalam menghadapi bencana kebakaran di Kapas Madya Baru yang berfokus kepada prabencana. Penelitian ini dilakukan dengan mengukur tingkat kapasitas masyarakat dan dilanjutkan dengan menggali faktorfaktor yang memengaruhi kapasitas tersebut di Kapas Madya Baru. Hasil dari penelitian ini dapat dijadikan sebagai masukan dalam pembuatan program peningkatan kapasitas masyarakat pada dokumen RISPK (Rencana Induk Sistem Proteksi Kebakaran) Kota Surabaya, maupun menjadi bahan referensi bagi penelitian serupa.

\section{METODE PENELITIAN}

\section{A. Teknik Pengumpulan Data}

Data dikumpulkan melalui survei primer secara offline dan survei sekunder secara online. Pada survei primer, metode untuk menangkap data karakteristik dan kapasitas masyarakat dilakukan melalui penyebaran kuisioner dengan 20 pertanyaan semiterbuka dan observasi lapangan. Pertanyaan semiterbuka adalah pertanyaan yang jawaban serta cara pengungkapannya tertutup namun responden dapat memberikan keterangan terhadap pertanyaan tersebut. Survei sekunder dilakukan dengan eksplorasi literatur dan kepustakaan yang memiliki relevansi dengan topik penelitian berupa dokumen perencanaan seperti RTRW, RPJMD, Masterplan Dinas Pemadam, dan berita/artikel di internet. Survei sekunder dilakukan untuk mencari fakta-fakta dan regulasi upaya pencegahan kebakaran sehingga diharapkan mendapatkan gap antara kondisi ideal dan kenyataan untuk penyusunan strategi.

\section{B. Variabel Penelitian}

Terdapat 15 indikator untuk mengukur tingkat kapasitas masyarakat yaitu kesiapan infrastruktur, kondisi lingkungan, sosialisasi, pelatihan dan simulasi bencana, pengetahuan tentang kebencanaan, penyusunan kebijakan, penyebaran informasi, organisasi tanggap bencana, sarana dan prasarana evakuasi, penanda bencana, kemitraan, Early Warning System, mekanisme pengambilan keputusan, penyebaran informasi kebencanaan, dan tindakan taktis. Serta terdapat 5 faktor yang dikonfirmasi kepada masyarakat untuk mengidentifikasi faktor yang berpengaruh yaitu usia, jenis kelamin, tingkat pendidikan, tingkat pendapatan, dan budaya. Pertanyaan dalam kuesioner disusun menggunakan skala Likert dengan skor $1-5$. Nilai 5 menunjukan bahwa responden sangat setuju terhadap pertanyaan, sedangkan nilai 1 menunjukan bahwa responden sangat tidak setuju dengan pernyataan.

\section{Populasi dan Sampel}

Populasi dalam penelitian ini adalah masyarakat di Kelurahan Kapas Madya Baru, sedangkan sampel penelitian ditentukan menggunakan teknik non-probability dengan metode purposive sampling. Purposive sampling adalah pengambilan sampel yang bergantung pada penilaian peneliti untuk memilih unit yang akan dipelajari . Penentuan jumlah sampel dihitung menggunakan rumus Slovin dan didapatkan jumlah reponden sebanyak 100 orang. Responden akan dipilih dengan 5 kriteria yang telah ditetapkan peneliti.

\section{Uji Validitas dan Reliabilitas}

Validitas dalam penelitian menyatakan derajat ketepatan alat ukur penelitian terhadap isi sebenarnya yang diukur. Uji validitas dilakukan menggunakan korelasi Bivariate Pearson (Produk Momen Pearson) dimana dinyatakan valid dengan syarat $r$ hitung $\geq r$ tabel (uji 2 sisi dengan sig. 0,05). Dari uji validitas menggunakan SPSS 25, didapatkan nilai validitas kuesioner di antara 0,201 hingga 0,721 yang berada di atas $r$ tabel dengan nilai 0,196 sehingga kuesioner valid dan dapat dijadikan instrumen untuk pengambilan data. Sedangkan, reliabilitas merujuk pada adanya konsistensi dan stabilitas nilai hasil skala pengukuran tertentu. Untuk menentukan reliabilitas, dilakukan dengan melihat nilai cronbach alpha. Jika cronbach alpha > 0.6 dan nilai alpha lebih besar dari $r$ tabel maka instrumen reliabel. Hasil uji reliabilitas menunjukkan nilai 0,735 yang berarti kuesioner memiliki reliabililitas yang dapat diterima.

\section{E. Uji Normalitas}

Agar data ordinal dari skala likert dapat digunakan untuk mengukur kapasitas masyarakat, diperlukan uji normalitas untuk mengetahui distribusi data [13]. Uji normalitas data dimaksudkan untuk memperlihatkan bahwa data sampel berasal dari populasi yang berdistribusi normal. Dasar dari pengambilan keputusan dalam uji normalitas menggunakan Kolmogorov-Smirnov adalah nilai signifikansi. Jika nilai signifikansi (Sig.) >0,05 maka data penelitian berdistribusi normal, sebaliknya jika nilai signifikansi (Sig.) $<0,05$ maka data penelitian tidak berdistribusi normal. Pada peneltian ini, uji normalitas menggunakan SPSS 25 didapatkan nilai Sig. menggunakan Kolmogorov-Smirnov adalah 0,088 yang berarti data dalam penelitian ini berdistribusi normal.

\section{F. Analisis Deskriptif}

Dalam penilaian kapasitas masyarakat, 15 indikator yang telah dirumuskan dari studi literatur akan divalidasi di masyarakat. Data yang dihasilkan akan diolah dengan analisis deskriptif menggunakan rumus Weighted Mean Score (WMS). Teknik analisis data WMS digunakan untuk menghitung ratarata skor responden untuk memperoleh gambaran umum dari setiap indikator. Hasilnya berupa tingkat kapasitas masyarakat dan kondisi kapasitas masyarakat sebagai input dalam 
penyusunan strategi. Berikut adalah rumus Weighted Mean Score (WMS).

$$
\mathrm{M}=\frac{\sum F \cdot(x)}{N}
$$

( $M$ adalah perolehan angka penafsiran, $F$ adalah frekuensi, $X$ adalah pembobotan skala nilai (skor), dan $N$ adalah jumlah responden).

Kemudian dilakukan penentuan tingkat kapasitas masyarakat menggunakan 5 kelas interval. Berikut adalah rumus yang digunakan untuk menghitung interval.

$$
\text { Interval }=\frac{\text { Nilai tertinggi }- \text { Nilai terendah }}{\text { Jumlah } \text { kelas }}
$$

Interpretasi skor kapasitas masyarakat dapat dilihat pada tabel berikut.

Tabel 1.

\begin{tabular}{cc}
\hline \multicolumn{2}{c}{ Interpretasi Skor Kapasitas } \\
\hline Skor & Kriteria \\
\hline $1,00-1,80$ & Tidak Baik \\
\hline $1,81-2,61$ & Kurang Baik \\
\hline $2,61-3,41$ & Cukup Baik \\
\hline $3,41-4,21$ & Baik \\
\hline $4,21-5,00$ & Sangat Baik \\
\hline Sumber: Kajian Literatur [14][15]
\end{tabular}

\section{G.Analisis Faktor}

Analisis faktor dapat digunakan untuk mereduksi beberapa atau ratusan variabel menjadi set yang lebih kecil, untuk mendapatkan konstruk dasar dan memperjelas interpretasinya. Analisis faktor dibedakan menjadi Confirmatory Factor Analysis (CFA) dan Explanatory Factor Analysis (EFA). Penelitian ini menggunakan EFA dengan tujuan untuk menemukan struktur laten dari variabel teramati dengan mengungkap faktor-faktor yang sama dan dimensi yang tersembunyi yang dapat mempengaruhi variabel terukur. Input dalam analisis faktor pada penelitian ini adalah 5 faktor berpengaruh yang diperoleh dari studi literatur dan divalidasi kepada masyarakat sehingga menghasilkan faktor yang mempengaruhi kapasitas masyarakat di Kapas Madya Baru.

Proses Explanatory Factor Analysis (EFA) terdiri dari 3 tahap. Pertama tahap adalah pemilihan indikator yang layak, tahap kedua adalah ekstraksi dan rotasi faktor, serta tahap ketiga adalah penamaan faktor. Pemilihan indikator yang layak dilakukan dengan melihat nilai Keiser-Meyers-Oklin (KMO) untuk melihat seberapa cocok data yang ada untuk analisis faktor. Barlett Test of Sphericity digunakan untuk mengetahui apakah ada korelasi signifikan antarindikator. Langkah selanjutnya adalah melihat pada anti-image matrics untuk melihat apakah sistem mampu membentuk faktor baru.

Tahap kedua yaitu ekstraksi dan rotasi faktor untuk memperjelas interpretasi dan menghilangkan ambiguitas. Metode ekstraksi yang digunakan adalah Principal Axis Factor dengan teknik rotasi Varimax. Principal Axis Factor dipilih dengan tujuan untuk menemukan faktor minimum berdasarkan korelasi sejumlah variabel dengan output berupa faktor, bukan komponen. Varimax dipilih karena metode rotasi ini membuat faktor-faktor saling independen. penentuan jumlah faktor yang terbentuk menggunakan Kaiser's Criterion dengan kriteria nilai eigen values lebih dari 1. Nilai Eigen merupakan total varians yang dapat dijelaskan oleh setiap faktor. Varians adalah keragaman atau keunikan yang ada di setiap variabel yang diamati.

Tahap ketiga yaitu penamaan faktor untuk pengelompokan indikator yang terbentuk. Penamaan faktor dilakukan dengan nama yang dapat mewakili faktor-faktor yang tebentuk.

\section{H.Analisis SWOT}

SWOT adalah metode perencanaan strategis yang digunakan untuk mengevaluasi kekuatan, kelemahan, peluang, dan ancaman dalam suatu proyek atau suatu spekulasi bisnis. Dalam analisis ini, SWOT diadaptasi untuk merumuskan potensi masalah yang memengaruhi kapasitas masyarakat dalam upaya pengurangan risiko kebakaran. Selanjutnya, dibentuk matriks SWOT yang kemudian digunakan untuk menghasilkan strategi.

\section{GAMBARAN UMUM WILAYAH}

\section{A. Gambaran Umum Wilayah Penelitian}

Wilayah penelitian adalah Kelurahan Kapas Madya Baru yang terletak di Kecamatan Tambaksari, Kota Surabaya. Kapas Madya Baru memiliki risiko tinggi kebakaran, kondisi kerentanan tinggi, dan bahaya sedang [3]. Sepanjang Tahun 2016 hingga 2019, Kapas Madya Baru mengalami 7 kali kebakaran dengan kerugian mencapai Rp1,5 miliar. Berikut adalah peta yang menunjukkan kondisi risiko bencana di Kelurahan Kapas Madya Baru.

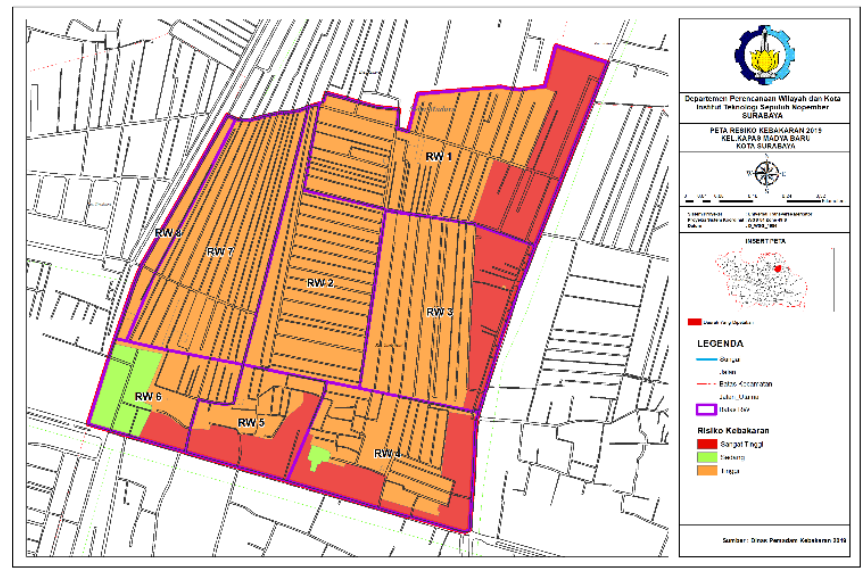

Gambar 1. Peta Kondisi Risiko Kebakaran

\section{HASIL DAN DISKUSI}

\section{A. Mengukur Tingkat Kapasitas Masyarakat}

Dari analisis Weight Means Score dimana skor akhir diperoleh dengan pembagian skor kriteria dengan jumlah responden, diperoleh tingkat kapasitas masyarakat dalam pengurangan risiko bencana kebakaran di Kelurahan Kapas Madya Baru berada pada level cukup baik dengan skor 2,77. Berikut adalah skor masing-masing indikator.

Tabel 2.

Tingkat Kapasitas Masyarakat

\begin{tabular}{lcc}
\hline \multicolumn{1}{c}{ Indikator } & Skor & Kriteria \\
\hline Kesiapan Infrastruktur & 3,2 & Cukup baik \\
\hline Kondisi lingkungan & 3,68 & Didominasi jawaban setuju 40\% \\
\hline
\end{tabular}




\begin{tabular}{lcc}
\hline Sosialisasi & 2,2 & $\begin{array}{c}\text { Kurang baik } \\
\text { Didominasi jawaban tdk setuju 65\% }\end{array}$ \\
\hline $\begin{array}{l}\text { Pelatihan dan Simulasi } \\
\text { Bencana }\end{array}$ & 1,56 & $\begin{array}{c}\text { Tidak baik } \\
\text { Didominasi jawaban tdk setuju 86\% }\end{array}$ \\
\hline $\begin{array}{l}\text { Pengetahuan tentang } \\
\text { kebencanaan }\end{array}$ & 3,56 & $\begin{array}{c}\text { Baik } \\
\text { Didominasi jawaban setuju 65\% }\end{array}$ \\
\hline Penyusunan Kebijakan & 2,1 & $\begin{array}{c}\text { Kurang baik } \\
\text { Didominasi jawaban tdk setuju 73\% }\end{array}$ \\
\hline Penyebaran Informasi & 3,74 & $\begin{array}{c}\text { Baik } \\
\text { Didominasi jawaban setuju 64\% }\end{array}$ \\
\hline $\begin{array}{l}\text { Organisasi tanggap } \\
\text { bencana }\end{array}$ & 1,47 & $\begin{array}{c}\text { Tidak baik } \\
\text { Didominasi jawaban tdk setuju 83\% }\end{array}$ \\
\hline $\begin{array}{l}\text { Sarana dan Prasarana } \\
\text { Evakuasi }\end{array}$ & 1,81 & $\begin{array}{c}\text { Kurang baik } \\
\text { Didominasi jawaban tdk setuju 80\% }\end{array}$ \\
\hline Pidak baik \\
\hline Penanda Bencana & 1,54 & Didominasi jawaban tdk setuju 81\% \\
\hline Kemitraan & 1,26 & $\begin{array}{c}\text { Tidak baik } \\
\text { Didominasi jawaban tdk setuju 91\% }\end{array}$ \\
\hline $\begin{array}{l}\text { Baik } \\
\text { Early Warning System }\end{array}$ & 3,76 & $\begin{array}{c}\text { Didominasi jawaban setuju 75\% } \\
\text { Baik }\end{array}$ \\
\hline $\begin{array}{l}\text { Mekanisme } \\
\text { Pengambilan } \\
\text { Keputusan }\end{array}$ & 4,07 & Didominasi jawaban setuju 92\% \\
\hline $\begin{array}{l}\text { Penyebaran Informasi } \\
\text { Kebencanaan }\end{array}$ & 4,71 & $\begin{array}{c}\text { Sangat Baik } \\
\text { Didominasi jawaban setuju 69\% }\end{array}$ \\
\hline Tindakan Taktis & 3,89 & $\begin{array}{c}\text { Baik } \\
\text { Didominasi jawaban setuju 79\% }\end{array}$ \\
\hline Cukup Baik \\
\hline Rata-rata & $\mathbf{2 , 7 7}$ &
\end{tabular}

\section{1) Kesiapan Infrastruktur}

Kepedulian masyarakat terhadap infrastruktur ditunjukkan dengan upaya meninggikan gapura sehingga mempermudah akses Dinas PMK. Selain itu, terdapat Permen PU 26/PRT/M/2008 yang mengatur kewajiban home industry untuk menyediakan alat pemadam ringan/APAR, sehingga menambah kesiapan masyarakat. Dari survei primer, didapatkan bahwa beberapa RT telah menyediakan peralatan pencegah kebakaran secara swadaya. Masalah yang muncul berdasarkan observasi lapangan adalah minimnya ketersediaan APAR dan sumber pemadam kebakaran di masyarakat, mengecilnya debit aliran sungai yang melalui daerah studi pada saat musim kemarau, terdapat bangunan di atas saluran tersier sehingga menghambat aliran ke sungai, dan kondisi akses jalan yang terhambat oleh bangunan di atas gapura, gangguan jalan, dan gang sempit.

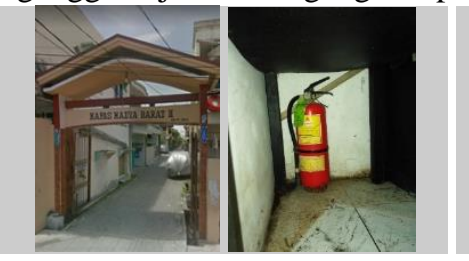

(a)

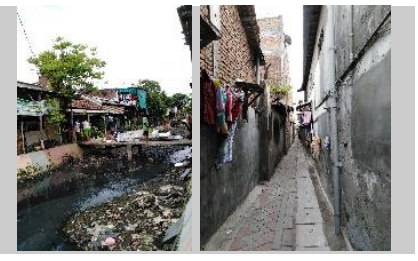

(b)
Gambar 2. Dokumentasi potensi kesiapan infrastruktur (a) dan Dokumentasi masalah kesiapan infrastruktur (b).

\section{2) Kondisi Lingkungan}

Kondisi lingkungan berkaitan dengan kepedulian masyarakat terhadap kondisi lingkungannya. Kepedulian tersebut berupa praktik penggunaan sumber api secara hatihati, adanya Perda No. 4 Tahun 2000 tentang larangan membakar sampah yang kemudian dijalankan sebagai aturan bersama di tingkat RT, serta adanya perlombaan yang diadakan Pemkot Surabaya berkaitan dengan kebersihan dan keamanan kampung yaitu Kampung Pendidikan Arek
Suroboyo (KP KAS). Dalam perlombaan itu, salah satu kategori pemenang adalah kampung aman yang melihat kesiapan kampung untuk antisipasi kebakaran. Sementara itu, masalah yang ditemukan adalah warga musiman kurang menjaga kebersihan lingkungan serta terdapat banyak bangunan semipermanen di sepanjang aliran sungai.

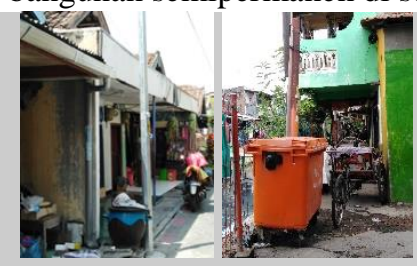

(a)

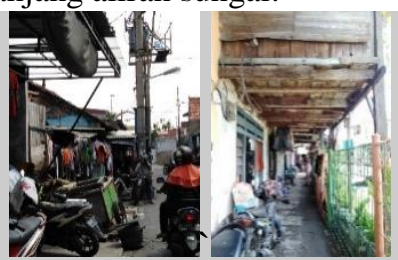

(b)
Gambar 3. Dokumentasi potensi kondisi lingkungan (a) dan Dokumentasi masalah kondisi lingkungan (b).

\section{3) Sosialisasi}

Berdasarkan survei primer, diketahui bahwa sosialisasi Dinas PMK kepada masyarakat di Kapas Madya Baru masih belum merata. Dalam praktiknya, Dinas PMK melakukan sosialisasi di kantor kelurahan dengan mengundang ketua RT dan RW. Sosialisasi dilakukan pada hari dan jam kerja, sehingga banyak pihak tidak dapat menghadiri sosialisasi karena bekerja. Selain itu, prosedur permintaan sosialisasi Dinas PMK belum terinformasikan secara merata ke masyarakat sehingga program sosialisasi dari Dinas PMK belum optimal.

\section{4) Pelatihan dan Simulasi Bencana}

Pelatihan dan simulasi berfungsi untuk memberikan gambaran sebuah kejadian kebakaran agar masyarakat mengetahui tindakan yang harus dilakukan untuk mengurangi dampaknya. Dalam simulasi kebakaran akan dipraktikkan cara memadamkan api dengan alat-alat sederhana maupun alat pemadam kebakaran. Berdasarkan penyebaran kuesioner, diketahui bahwa sebagian besar masyarakat belum mendapatkan pelatihan dan simulasi.

5) Pengetahuan tentang Kebencanaan

Pengetahuan tentang kebencanaan berkaitan dengan pengetahuan masyarakat terhadap karakteristik bahaya seperti penyebab kebakaran, kondisi kerentanan yang ada, dan kemampuan masyarakat untuk menanggulangi kebakaran. Mayoritas masyarakat mengetahui dan sadar akan kerentanan wilayahnya, sedangkan kemampuan memadamkan api saat kebakaran mengandalkan peralatan sederhana yang ada di sekitar misalnya timba, kain yang dibasahi, dan lainnya. Pengetahuan masyarakat didukung dari sosialisasi yang dilakukan sales kompor/LPG. Permasalahan yang ditemukan berupa rendahnya pengetahuan tentang penyebab kebakaran yang berhubungan dengan arus listrik.

\section{6) Penyusunan kebijakan}

Penyusunan kebijakan berkaitan dengan keterlibatan masyarakat berupa pemberian saran dan usulan terhadap kebijakan penanggulangan bencana kebakaran sesuai Perka BNPB No. 11 Tahun 2014 tentang Peran Serta Masyarakat dalam Penyelenggaraan Penanggulangan Bencana dan Permen PU No. 25 Tahun 2008 tentang Rencana Induk Sistem Proteksi Kebakaran (RISPK). Berdasarkan jawaban 
masyarakat, masyarakat tidak dapat/tidak mengetahui cara mengusulkan pendapat mereka. Hal tersebut disebabkan penyusunan kebijakan dan perencanaan mitigasi kebakaran dilakukan berdasarkan evaluasi Dinas PMK terhadap program dan kegiatan di masyarakat.

7) Penyebaran Informasi

Informasi tersebar di masyarakat melalui kegiatan rutin seperti arisan, yasinan bapak-bapak, yasinan ibu-ibu, rapat $\mathrm{PKK}$, rapat $\mathrm{RT} / \mathrm{RW}$, kerja bakti, door to door bersamaan dengan penarikan iuran rutin, serta beberapa RT memiliki WhatsApp Group. Cara yang dinilai paling efektif adalah tatap muka karena terkesan lebih sopan.

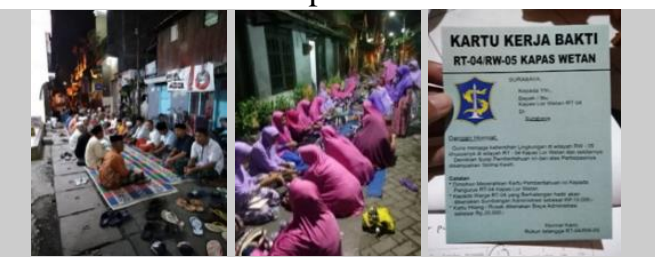

Gambar 4. Dokumentasi Penyebaran Informasi.

\section{8) Organisasi Tanggap Bencana}

Organisasi tanggap bencana berkaitan dengan keberadaan Satuan Realawan Kebakaran (Satlakar) dan kinerja organisasi tersebut dilihat dari keaktifan sesuai arahan dalam Perwali No. 57 Tahun 2014 tentang Satlakar Kota Surabaya. Berdasarkan jawaban masyarakat, tidak ada aktivitas organisasi tersebut di Kelurahan Kapas Madya Baru. Bahkan, banyak responden yang mengaku tidak mengetahui tentang organisasi tanggap kebakaran tersebut. Organisasi yang aktif berupa Pemberdayaan Kesejahteraan Keluarga (PKK), Juru Pemantau Jentik (Jumantik), dan Lembaga Ketahanan Masyarakat Kelurahan (LKMK). Sementara itu, karang taruna hanya aktif saat menjelang peringatan HUT RI. Himbauan tentang kebakaran biasanya diselipkan oleh PKK dan Jumantik dalam acara-acara rutin. Saat ini, menurut keterangan Dinas PMK, satlakar telah dinonaktifkan dan diganti program unggulan yang dirilis tahun 2018 yaitu "Pelajaran On The Spot" yang lebih efektif karena masyarakat secara langsung mendapatkan pembinaan. Akan tetapi, belum ada regulasi yang bersifat menonaktifkan Perwali No. 57 Tahun 2014 tentang Satuan Relawan Kebakaran Kota Surabaya.

9) Sarana dan Prasarana Evakuasi

Sarana prasarana evakuasi berkaitan dengan kesiapan sarana dan prasarana evakuasi. Kesiapan masyarakat terhadap sarana prasarana evakuasi masih rendah. Masyarakat tidak memahami tentang pentingnya sarana prasarana evakuasi, sehingga masyarakat belum memikirkan cara evakuasi pada gang buntu dan gang sempit. Untuk tempat evakuasi, masyarakat menyebutkan lokasi yang berpotensi seperti sepanjang gang, musala, balai RT dan RW, namun belum ada pembahasan di masyarakat untuk menyepakati hal tersebut.

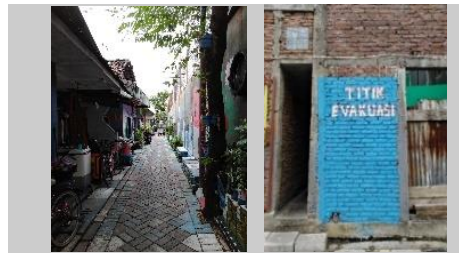

(a)

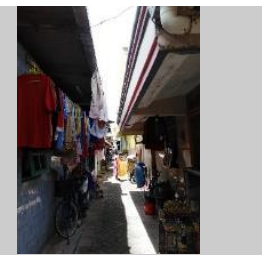

(b)
Gambar 5. Dokumentasi potensi sarana dan prasarana evakuasi (a) dan Dokumentasi masalah sarana dan prasarana evakuasi (b).

\section{0) Penanda Bencana}

Penanda bencana berkaitan dengan keberadaan dan kondisi penanda bencana seperti papan informasi kebakaran, peta rawan bencana, dan tanda bahaya kebakaran. Mayoritas masyarakat menyatakan tidak memiliki penanda bencana yang memberikan informasi penyelamatan diri.

\section{1) Kemitraan}

Kemitraan berkaitan dengan keberadaan mitra berupa Lembaga Swadaya Masyarakat (LSM), Non-Governmnet Organization (NGO) dan pihak swasta yang membantu pengurangan risiko kebakaran melalui Corporate Social Responsibility (CSR), dana hibah, dan pembangunan infrastruktur kebencanaan. Pemerintah Kota Surabaya belum menjalin kerjasama dengan pihak ketiga dalam penanganan kebakaran.

\section{2) Early Warning System}

Early Warning System berarti keberadaan dan keefektifan sistem peringatan dini baik secara konvensional maupun modern. Peringatan dini bencana secara manual berjalan efektif dengan mengandalkan kedekatan dan solidaritas masyarakat. Penyebaran informasi darurat dilakukan secara manual dari mulut ke mulut dan pengeras suara masjid karena kondisi rumah yang padat dengan kepedulian masyarakat yang cukup tinggi. Masalah yang muncul adalah belum adanya sistem pendeteksi kebakaran yang cepat sehingga dalam banyak kasus kebakaran baru terdeteksi ketika api sudah membesar.

\section{3) Mekanisme Pengambilan Keputusan}

Mekanisme pengambilan keputusan berkaitan dengan keberadaan tokoh masyarakat untuk mengarahkan respon tanggap darurat. Tokoh masyarakat di daerah studi berupa pengurus $\mathrm{RT} / \mathrm{RW}$, tokoh agama, sesepuh kampung dan lainnya. Di daerah studi, tokoh masyarakat menjadi contoh dan kunci penggerak masyarakat. Selain mengarahkan untuk pemadaman awal, pengurus RT juga memimpin proses evakuasi korban maupun harta benda yang terbakar serta melakukan pelaporan ke dinas terkait. Selain itu, pengurus RT berperan dalam edukasi tentang command center 112 .

\section{4) Penyebaran Informasi Kebencanaan}

Terdapat peran media seperti Suara Surabaya (SS) dalam penyebaran informasi kebencanaan melalui siaran interaktif, Pendengar dapat mengetahui situasi dan kondisi sebagian wilayah Surabaya setiap waktu, karena SS menerima aduan kejadian dari masyarakat

\section{5) Tindakan Taktis}

Berkaitan dengan respon pengurangan dampak kebakaran pada saat terjadi kebakaran yang meliputi pemadaman awal, 
respon jalan dan lainnya. Dalam merespon kebakaran, masyarakat mengandalkan gotong royong yang tinggi untuk melakukan pemadaman awal dan penyiapan akses Dinas PMK. Akan tetapi, antusiasme masyarakat untuk melihat dan mendokumentasikan bencana tinggi sehingga menghambat pemadaman api.

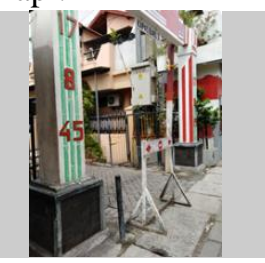

(a)

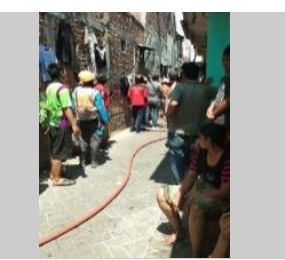

(b)
Gambar 6. Dokumentasi potensi tindakan taktis (a) dan Dokumentasi masalah tindakan taktis (b).

\section{B. Mengidentifikasi Faktor Berpengaruh Terhadap Kapasitas Masyarakat}

1) Pemilihan Indikator yang layak

Pemilihan indikator yang layak dilakukan dengan tiga indikator, pertama yaitu skor $K M O>0,5$ untuk mengetahui kecocokan data yang ada untuk analisis faktor, nilai signifikansi pada Barlett Test of Sphericity sig $<0,5$ untuk mengetahi korelasi antar indikator, dan nilai anti-image matrics $p>0,5$ untuk mengetahui hubungan yang terpola dalam data yang dianalisis. Analisis faktor dapat dilanjutkan jika sistem memenuhi tiga persyaratan dalam pemilihan indikator yang layak.

Skor $K M O$ pada penelitian ini sebesar 0.557 dengan taraf signifikansi 0.000 , yang berarti sampel yang digunakan cukup memadai untuk dianalisis faktor dan ada hubungan terpola dalam data. Dari gambar dibawah, skor anti-image variabel tingkat penghasilan tidak memungkinkan pembentukan faktor baru karena dibawah 0,5. Langkah yang dapat ditempuh adalah menambah jumlah sampel, atau menghapus item tingkat penghasilan. Langkah yang dipilih peneliti adalah menghapus item dari analisis faktor.

Faktor tingkat penghasilan tidak dipertimbangkan dalam penelitian ini karena menunjukkan korelasi yang lemah dengan variabel lainnya. Berdasarkan sebaran data, variabel tingkat penghasilan tidak dominan memengaruhi kapasitas masyarakat. Mayoritas responden menyatakan tingkat penghasilan masyarakat di Kapas Madya Baru tidak mempengaruhi kemampuan seseorang untuk mengantisipasi kebakaran. Hal tersebut linier dengan fakta di wilayah studi bahwa pencegahan kebakaran belum menjadi isu penting sejauh belum terjadi kasus kebakaran disekitar lingkungannya. Berikut adalah tabel anti-image matrics.

Tabel 3.

Koefisien Korelasi Anti-Image

\begin{tabular}{lc}
\multicolumn{2}{c}{ Koefisien Korelasi Anti-Image } \\
\hline \multicolumn{1}{c}{ Indikator } & Skor \\
\hline Usia & 0,549 \\
\hline Jenis Kelamin & 0,636 \\
\hline Tingkat Pendidikan & 0,550 \\
\hline Tingkat Penghasilan & 0,356 \\
\hline Budaya & 0,585 \\
\hline
\end{tabular}

2) Ekstraksi dan Rotasi Faktor

Hasil ekstraksi faktor dapat dilihat pada Tabel.4 di bawah ini. Dari hasil analisis SPSS, didapatkan bahwa faktor yang terbentuk dengan nilai eigen values di atas 1 sebanyak 2 faktor. Pada kondisi awal, faktor 1 menjelaskan sebesar $41,7 \%$, sedangkan faktor 2 dapat menjelaskan $67,1 \%$ terhadap total varians. Nilai ini cukup baik karena total varians yang dapat dijelaskan melebih 50\%. Akan tetapi, setelah dilakukan rotasi, dari kedua faktor yang terbentuk tersebut hanya dapat menjelaskan $34 \%$ dari total varians. Artinya, sebanyak $66 \%$ faktor yang tebentuk berasal dari faktor di luar penelitian. Penurunan tersebut dikarenakan pada proses rotasi menggunakan metode varimax, terdapat proses normalisasi yang disebut Kaisar Normalisasi.

Tabel. 4

Hasil Ekstraksi Faktor

\begin{tabular}{cccccc}
\hline \multirow{3}{*}{ Faktor } & \multicolumn{3}{c}{ Sebelum rotasi } & \multicolumn{2}{c}{ Setelah rotasi } \\
\cline { 2 - 6 } & \multirow{2}{*}{ Total } & $\begin{array}{c}\text { \% } \\
\text { Varians }\end{array}$ & $\begin{array}{c}\text { \% } \\
\text { Kumulatif }\end{array}$ & $\begin{array}{c}\text { \% } \\
\text { Varians }\end{array}$ & $\begin{array}{c}\text { \% } \\
\text { Kumulatif }\end{array}$ \\
\hline $\mathbf{1}$ & 1,667 & 41,680 & 41,680 & 21,533 & 21,533 \\
\hline $\mathbf{2}$ & 1,018 & 25,446 & 67,126 & 12,539 & 34,072 \\
\hline
\end{tabular}

3) Penamaan Faktor

Penamaan faktor lebih merupakan 'seni' karena tidak ada aturan untuk penamaan faktor. Akan tetapi, umumnya digunakan nama yang dapat mewakili variabel dalam faktor. Hasil dari proses ekstraksi dan rotasi dari indikator-indikator tersebut dapat mengungkap adanya 2 faktor yang memengaruhi kapasitas masyarakat terhadap upaya pengurangan risiko bencana kebakaran di Kapas Madya Baru. Faktor pertama dinamai Kualitas SDM yang meliputi variabel usia dan tingkat pendidikan dengan kontribusi sebesar $22 \%$ terhadap total varians. Sedangkan, faktor kedua dinamai Tata Kelola yang terdiri dari jenis kelamin dan budaya dengan kontribusi sebesar $13 \%$ terhadap varians faktor yang terbentuk. Berikut adalah nilai faktor loading setelah dilakukan rotasi penghilangan variabel tingkat penghasilan.

Tabel 5.

Faktor Matrix, Eigenvalues, dan Varians

\begin{tabular}{lcc}
\hline \multirow{1}{*}{ Indikator } & \multicolumn{2}{c}{ Faktor Bentukan } \\
\cline { 2 - 3 } & Kualitas SDM & Tata Kelola \\
\hline Usia & 0,671 & \\
\hline Jenis Kelamin & & 0,498 \\
\hline $\begin{array}{l}\text { Tingkat } \\
\text { Pendidikan }\end{array}$ & 0,611 & \\
\hline Budaya & & 0,452 \\
\hline Eigenvalues & 0,861 & 0,502 \\
\hline \% Varians & 21,533 & 12,539 \\
\hline
\end{tabular}

- Faktor Kualitas SDM

Faktor kualitas SDM terbentuk dari korelasi kuat antara variabel usia dan tingkat pendidikan. Usia memengaruhi daya tangkap, pola pikir, pengetahuan, dan kematangan dalam mengambil keputusan. Dilihat dari data BPS, karakteristik masyarakat menurut usia di Kelurahan Kapas Masya Baru dapat digambarkan berbentuk piramida penduduk muda/expansive, di mana menimbulkan dampak positif atau negatif terhadap kapasitas masyarakat. Banyaknya penduduk usia muda akan berdampak pada banyaknya SDM yang melek teknologi, memiliki tingkat pengetahuan yang baik, dan pola pikir yang lebih berkembang serta diharapkan lebih tanggap daripada orang tua. Sementara itu, penduduk usia tua dapat dilihat sebagai potensi karena memiliki pemikiran yang lebih 
matang sehingga dalam rapat RT/RW biasanya dilibatkan untuk memberikan masukan yang disebut sesepuh kampung.

Akan tetapi, banyaknya penduduk usia muda tanpa dilakukan edukasi, akan berpotensi meningkatkan kecerobohan penggunaan sumber api. Menurut sebuah penelitian yang mencari korelasi usia dengan perilaku menggunakan listrik, dinyatakan bahwa terdapat korelasi positif yang signifikan antara usia dan perilaku menumpuk steker alat elektronik banyak pada satu sumber listrik. Hal ini juga dapat ditemukan di wilayah studi pada fenomena banyaknya anak muda yang berkumpul di warung kopi untuk mencari wifi dan bermain game. Aktivitas ini akan membahayakan ketika banyaknya stop kontak yang disediakan untuk mengisi daya ponsel berdekatan dengan sumber api dari pengguna rokok di warung tersebut atau kebiasan menggunakan steker dengan beban berlebihan selama berjamjam.

Data tingkat pendidikan di Kelurahan Kapas Madya Baru menunjukkan sebagian besar masyarakat memiliki tingkat pendidikan yang rendah dilihat dari besarnya penduduk tidak sekolah sebanyak 13.249 dan tidak tamat sekolah sebanyak 1.337 [5]. Masyarakat dengan tingkat pendidikan yang rendah perlu diberikan pemahaman yang terus menerus tentang bahaya kebakaran dengan cara yang mudah diterima. Penduduk dengan tingkat pendidikan yang baik dapat menjadi potensi dalam edukasi kebakaran ke masyarakat sekitar. Akan tetapi, penduduk dengan tingkat pendidikan yang tinggi di Kelurahan Kapas Madya Baru mayoritas sibuk bekerja dan pulang larut malam, sehingga tidak memiliki banyak waktu untuk bersosialisasi dengan masyarakat sekitar.

- Faktor Tata Kelola

Peningkatan kapasitas masyarakat dapat dilakukan salah satunya dengan peningkatan tata kelola masyarakat. Dengan pendekatan yang berbasis gender dan kebudayaan yang sesuai, masyarakat akan lebih mudah diarahkan dan partisipasi masyarakat dapat ditingkatkan. Jenis kelamin dalam penelitian ini memengaruhi pengalaman bencana, respons terhadap bencana, serta dampak atau risiko bencana. Mayoritas responden menyatakan bahwa wanita memiliki pengalaman bencana yang rendah, respons bencana yang dipenuhi dengan kepanikan, dan risiko bencana yang lebih tinggi dari laki-laki. Akan tetapi dengan edukasi yang terus menerus, ibu-ibu akan meningkatkan kemampuannya dalam merespon bencana setidaknya mampu mengurangi kepanikan dan mengetahui apa yang harus dilakukan dalam situasi darurat.

Pengaruh kebudayaan yang sangat kuat memengaruhi anggota masyarakat di wilayah studi berkaitan dengan keagamaan. Dari distribusi jumlah penduduk menurut kepercayaan, mayoritas penduduk beragama Islam. Dalam Islam, kegiatan-kegiatan keagamaan biasa menjadi agenda rutin yang terus dijalankan seperti yasinan bapak-bapak, yasinan ibu-ibu, peringatan maulid nabi, dan lain sebagainya. Mayoritas responden sepakat bahwa kebudayaan adalah salah satu jendela bagi seseorang untuk menyatu dengan nilai-nilai baik di sekitarnya dan memengaruhi motivasi seseorang untuk berpikir, menafsirkan, menilai, mengambil tindakan, serta mengambil keputusan di situasi tanggap darurat.
Seseorang yang tergabung dalam komunitas keagamaan, akan cenderung lebih tanggap dan peduli karena memiliki sense of belonging yang tinggi terhadap sekitar, seperti ajaran agama yang dianutnya. Berdasarkan kondisi di lapangan, masyarakat sangat menghormati tokoh agama, sehingga pengetahuan yang diselipkan dalam kegiatan keagamaan mudah diserap oleh masyarakat. Akan tetapi, belum ditemukan kegiatan kebudayaan di Kelurahan Kapas Madya Baru yang disisipi pemberian pengetahuan mitigasi bencana.

\section{4) Faktor Temuan}

Dari keempat faktor yang berpengaruh terhadap kapasitas masyarakat dalam antisipasi kebakaran, ternyata ditemukan beberapa faktor tambahan yang disebutkan oleh responden. Faktor-faktor tersebut adalah kesadaran individu, pengalaman bencana, dan tokoh masyarakat. Faktor temuan ini akan diintegrasikan dengan faktor yang memengaruhi kapasitas masyarakat untuk merumuskan strategi.

\section{Merumuskan Strategi Peningkatan Kapasitas}

Strategi dirumuskan dengan analisis SWOT dimana matriks SWOT disusun dari potensi dan masalah yang telah diidentifikasi pada sasaran 1 dan 2. Berikut adalah elemen pembentuk pada masing-masing matriks.

\section{Strength (Kekuatan dari internal)}

1. Ada beberapa RT yang telah mengantisipasi kebakaran dengan peninggian gapura, penyediaan hidran, dan alat pemadam api ringan (APAR) dari swadaya masyarakat

2. Masyarakat sudah mempraktikkan penggunaan alat memasak, lilin, dan korek api secara hati-hati

3. Proses penyebaran informasi mitigasi berjalan efektif melalui kegiatan masyarakat dan door to door

4. Terdapat organisasi aktif masyarakat yang berpotensi mendukung penyadaran masyarakat seperti PKK, Jumantik, dan LKMK

5. Peringatan dini bencana secara manual berjalan efektif dengan mengandalkan kedekatan dan solidaritas masyarakat

6. Tokoh masyarakat responsif dan sesuai kebutuhan masyarakat

7. Banyak masyarakat sudah mengenal command center 112

8. Gotong royong masyarakat tinggi untuk merespon bencana seperti pemadaman awal dan respon penutupan jalan

\section{Weakness (Kelemahan dari internal)}

1. Masyarakat tidak memahami prosedur pengajuan proposal tentang permintaan sosialisasi Dinas PMK ke masyarakat

2. Pengetahuan masyarakat tentang bahaya kebakaran yang disebabkan oleh arus listrik masih rendah

3. Masyarakat kurang terlibat dalam penyusunan kebijakan kebencanaan

4. Tidak aktifnya Satlakar (Satuan Relawan Kebakaran) di masyarakat

5. Pemahaman masyarakat tentang pentingnya sarana prasarana evakuasi masih rendah 
6. Tidak ada kesepakatan tentang tempat evakuasi, jalur evakuasi, dan petunjuk evakuasi

7. Evakuasi pada gang buntu dan gang sempit

8. Masyarakat tidak memiliki penanda bencana seperti papan informasi bencana, peta rawan bencana, dan tanda bahaya kebakaran

9. Belum adanya sistem pendeteksi kebakaran yang cepat

10. Antusiasme masyarakat untuk melihat dan mendokumentasikan bencana tinggi sehingga menghambat pemadaman api

\section{Opportunities (Peluang dari eksternal)}

1. Adanya aturan tentang larangan membakar sampah

2. Adanya aturan yang mewajibkan home industry untuk menyediakan alat pemadam

3. Adanya perlombaan yang diadakan Pemkot Surabaya berkaitan dengan kebersihan dan keamanan kampung

4. Terdapat beberapa pihak luar seperti sales LPG dan regulator yang membantu memberikan penyadaran upaya antisipasi kebakaran

5. Terdapat tempat evakuasi potensial seperti sepanjang gang, mushola, serta balai RT dan RW

6. Terdapat peran media seperti Suara Surabaya dalam penyebaran informasi kebencanaan melalui siaran interaktif

7. Dinas PMK memiliki program "Pelajaran on the Spot" yang melakukan sosialisasi kebakaran dan membina masyarakat melalui pembagian tugas tanggap darurat

8. Terdapat Perwali No. 57 Tahun 2014 sebagai dasar keterlibatan masyarakat dalam penanggulangan kebakaran dalam bentuk Satlakar

\section{Threat (Ancamana dari eksternal)}

1. Dilalui sumber air berupa sungai dengan debit air yang mengecil pada saat kemarau

2. Terdapat bangunan di atas saluran tersier sehingga menghambat aliran ke sungai

3. Akses jalan terhambat oleh bangunan di atas gapura, gangguan jalan, dan gang sempit

4. Terdapat banyak bangunan semipermanen di sepanjang aliran sungai

5. Warga musiman kurang menjaga kebersihan lingkungan

6. Sosialisasi yang dilakukan pemerintah belum merata kepada seluruh masyarakat

7. Pelaksanaan sosialisasi dari Dinas PMK Kebakaran terjadwal dan kurang fleksibel terhadap kesediaan masyarakat

8. Pelatihan dan simulasi tentang upaya tanggap darurat yang dilakukan pemerintah belum merata

9. Masyarakat tidak menjalin kerja sama dengan mitra seperti swasta dan LSM

Hasil analisis SWOT berupa 16 strategi peningkatan kapasitas pada tahap mitigasi, 4 strategi peningkatan kapasitas pada tahap kesipasiagaan, dan 4 strategi peningkatan kapasitas pada tahap peringatan dini. Berikut adalah hasil strategi peningkatan kapasitas masyarakat pada tahap mitigasi : a. Mendukung penyediaan alat pemadam di masyarakat secara swadaya

b. Mengadaptasi regulasi larangan membakar sampah ke dalam aturan antisipasi kebakaran yang disepakati di tingkat RT/RW

c. Meningkatkan intensitas "Pelajaran On The Spot" untuk edukasi bahaya kebakaran

d. Memberikan stimulus berupa kemudahan izin sales resmi LPG dan regulator yang membantu memberikan edukasi kebakaran

e. Memaksimalkan peran tokoh masyarakat dalam sosialisasi kebakaran melalui forum masyarakat

f. Memanfaatkan organisasi aktif masyarakat dalam mengedukasi kebakaran

g. Mengembangkan sistem mitigasi kebakaran berbasis teknologi yang berisi informasi cara penanggulangan kebakaran, pelaporan kejadian, dan pengajuan permintaan sosialisasi PMK secara mudah, cepat, dan efektif

h. Mengintegrasikan elemen kebudayaan dan keagamaan dalam edukasi masyarakat

i. Menertibkan kewajiban penyediaan APAR untuk home industry berdasarkan Permen PU 26/PRT/M/2008

j. Kerjasama antara Dinas PMK, PLN, dan media untuk melakukan edukasi praktik aman penggunaan listrik

k. Mengadakan jaring aspirasi masyarakat dalam perencanaan dan penyusunan kebijakan kebencanaan

1. Evaluasi pelaksanaan Permen PU No. 20 Tahun 2009 dan Perwali No. 57 Tahun 2014 tentang Satlakar

m.Mengoptimalkan perlombaan tahunan yang diselenggarakan Pemkot Surabaya untuk meningkatkan kesadaran dan pemahaman masyarakat tentang kebakaran

n. Mengembangkan sistem jaringan suplai air untuk daerah yang tidak dilayani sungai

o. Menyediakan APAR dan hidran di setiap RT/RW di daerah dengan kerentanan sangat tinggi

p. Penertiban bangunan yang menghambat fungsi saluran air dan bangunan semi permanen

Berikut adalah hasil strategi peningkatan kapasitas masyarakat pada tahap kesiapsiagaan:

a. Membuka peluang kerjasama pemerintah dengan mitra untuk menyediakan infrastruktur penanggulangan kebakaran

b. Membuat Standard Operating Procedure (SOP) evakuasi yang disepakati masyarakat dengan Dinas PMK khususnya di daerah dengan kerentanan sangat tinggi

c. Mengadakan pelatihan dan simulasi evakuasi kebakaran

d. Membuat signage/penanda bencana yang memberikan informasi penyelamatan diri di setiap RT, khususnya di daerah dengan kerentanan sangat tinggi

Berikut adalah hasil strategi peningkatan kapasitas masyarakat pada tahap peringatan dini:

a. Mengembangkan sistem peringatan dini yang cepat di daerah dengan kerentanan tinggi

$b$. Membuat kesepakatan konsep peringatan dini di lingkungan saat program "Pelajaran On The Spot" 
c. Pelaksanaan program "Pelajaran On The Spot" melibatkan tokoh masyarakat dalam mengatur pembagian tugas tanggap darurat sesuai dengan kesediaan waktu masyarakat

d. Edukasi nelalui media masa tentang respons jalan ketika terjadi kebakaran

\section{KESIMPULAN}

Strategi pengurangan risiko kebakaran dengan peningkatan kapasitas masyarakat dapat dilakukan dengan mengkaji level dan faktor penyebab kapasitas masyarakat. Kapasitas masyarakat di Kelurahan Kapas Madya Baru berada pada level cukup baik dengan faktor yang memengaruhi yaitu kualitas SDM dan tata kelola. Strategi yang dirumuskan dalam penelitian ini dibagi menjadi 3 tahap. Strategi pada tahap mitigasi berfokus pada peningkatan kesiapan alat pemadam, penertiban bangunan yang menghambat pemadaman api, pengembangan sistem jaringan supply air, pembuatan aturan antisipasi kebakaran di lingkup RT, peningkatan sosialisasi dan simulasi melalui kerjasama elemen masyarakat, peningkatan pemahaman masyarakat melalui perlombaan, pengembangan sistem mitigasi berbasis teknologi, edukasi praktik aman penggunaan listrik, jaring aspirasi masyarakat dalam penyusunan kebijakan, dan evaluasi Perwali No. 57 Tahun 2014. Tahap kesiapsiagaan berfokus kepada pembuatan konsep evakuasi disertai edukasinya, pembuatan penanda bencana, dan kemitraan. Tahap peringatan dini berfokus pada pengembangan sistem peringatan dini dan pembagian tugas tanggap darurat. Strategi dalam penelitian ini dapat diterapkan di wilayah dengan karakteristik dan level kapasitas yang sama dengan wilayah studi yaitu Kapas Madya Baru. Kelemahan dari penelitian ini adalah belum memperhatikan kelompok rentan sebagai objek amatan sehingga penelitian ini dapat menjadi masukan untuk penelitian serupa dengan mempertimbangkan responden kelompok rentan (ibu hamil, anak-anak, lansia, kaum difabel, dan lainnya).

\section{UCAPAN TERIMA KASIH}

Penulis mengucapkan terimakasih kepada ketua RT dan RW di Kelurahan Kapas Madya Baru selaku responden penelitian serta Dinas PMK Kota Surabaya yang banyak memberikan data selama penelitian.

\section{DAFTAR PUSTAKA}

[1] A. Heryana, "Pengertian Dan Jenis Bencana," Researchgate.Net, 2020.

[2] F. S. Nurwulandari, "KAJIAN MITIGASI BENCANA KEBAKARAN DI PERMUKIMAN PADAT," INFOMATEK, 2017, doi: 10.23969/infomatek.v18i1.506.

[3] PMK, "Laporan Penyusunan Perencanaan Analisa Jangkauan Mitigasi Bencana Kebakaran Kota Surabaya," 2019.

[4] D. F. Saraswati and A. B. Cahyono, "Analisis Daerah Risiko Bencana Kebakaran di Kota Surabaya dengan Menggunakan Sistem Informasi Geografis," J. Tek. ITS, vol. 6, no. 2, pp. 1-4, 2017, doi: 10.12962/j23373539.v6i2.24410.

[5] Badan Pusat Statistik Kota Surabaya, "Kecamatan Tambaksari dalam Angka 2019,” p. 65 halaman, 2019.

[6] PMK kota Surabaya, "Laporan Kejadian Kebakaran 2019," 2019.

[7] D. Fitrah and A. Budi, "Analisis Daerah Risiko Bencana Kebakaran di Kota Surabaya Menggunakan Sistem Informasi Geografis," J. Tek. ITS, 2017.
[8] BNBP, "Kepala Badan Nasional Penanggulangan Bencana Tentang Daftar Isi Kepala Badan Nasional Penanggulangan Bencana Tahun 2012 Tentang Pedoman Umum Pengkajian Risiko 2 . Lampiran Peraturan," 2012.

[9] FAO, Disaster risk management systems analysis : A Guide Book. Rome, 2008.

[10] R. A. Kowara and T. Martiana, "Analisis Sistem Proteksi Kebakaran sebagai Upaya Pencegahan dan Penanggulangan Kebakaran (Studi di PT. PJB UP Brantas Malang),"J. Manaj. Kesehat. Yayasan Dr. Soetomo, 2017. 